\title{
Teaching NeuroImages: Morning glory disc anomaly
}

Guillaume Poillon, MD, Perrine Gillard, MD, and Augustin Lecler, MD, PhD

Neurology ${ }^{\circledR}$ 2018;91:e1457-e1458. doi:10.1212/WNL.0000000000006325
Correspondence

Dr. Lecler

alecler@for.paris

Figure Funduscopy and brain MRI

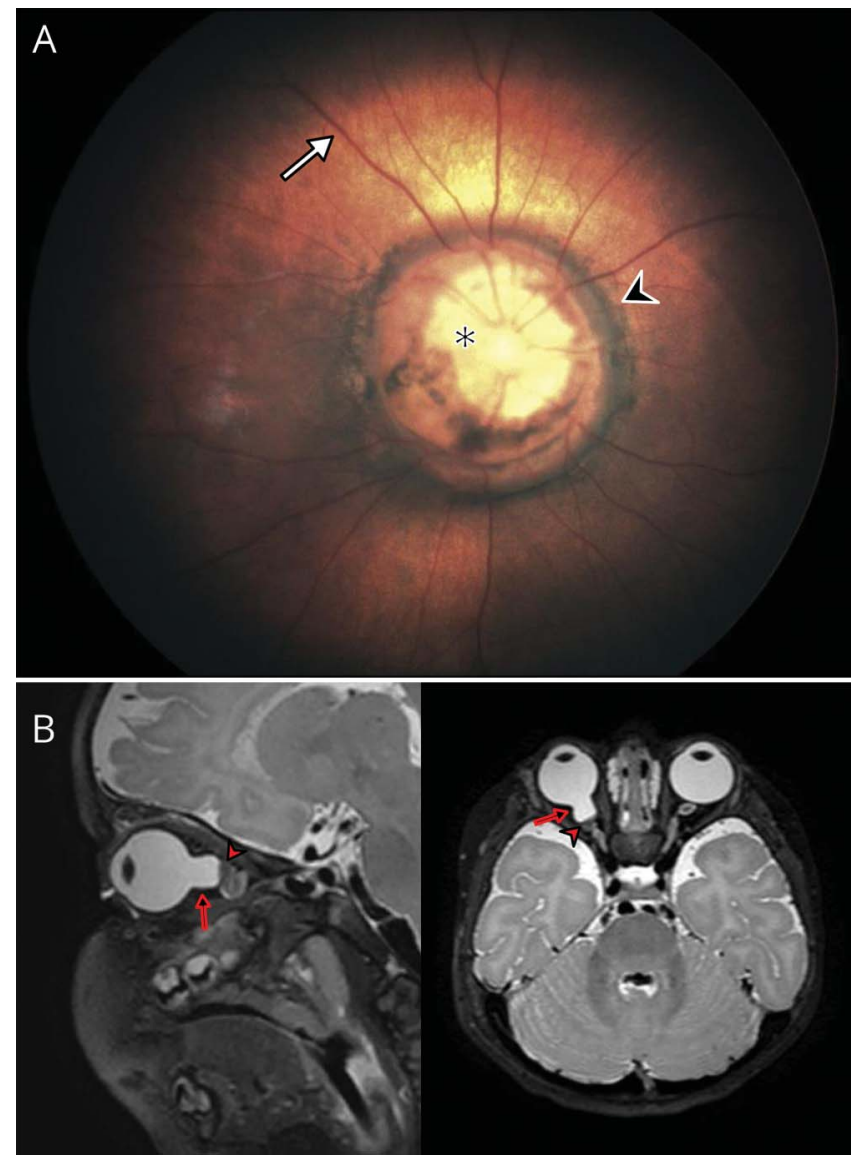

(A) Right eye funduscopy. Funduscopy shows a funnel-shaped excavation of the optic disc (asterisk), a pigmented ring in the peripapillary area (arrowhead), and a radial aspect of the retinal vessels (arrow). (B) Brain MRI. T2weighted images find the excavation (arrow) and glial tuft at the optic nerve insertion (arrowhead).
A 7-month-old girl presented with strabismus. Funduscopy (figure, A) revealed a typical morning glory disc anomaly (MGDA) of the right eye, including an enlarged funnel-shaped excavation of the optic disc, a peripapillary pigmented ring, and a radial aspect of the retinal vessels. Brain MRI (figure, B) showed excavation and abnormal tissue at the optic nerve insertion consistent with glial tuft. The symptoms caused by a MGDA are various and not always present: variable visual acuity (often poor) for the affected eye, visual field defects, and enlarged blind spot are the most common symptoms. Serous retinal detachments can occur. The pathology is usually unilateral. MRI helps in making the diagnosis and detecting associated intracranial abnormalities, ${ }^{1}$ especially midline anomalies like transphenoidal basal

\section{MORE ONLINE}

$\rightarrow$ Teaching slides

links.lww.com/WNL/

A695 
encephalocele and moyamoya syndrome. There is no treatment for MGDA; however, optimizing visual acuity is important to prevent amblyopia. ${ }^{2}$

\section{Author contributions}

G. Poillon: study concept and design, acquisition of data, analysis and interpretation. P. Gillard: analysis and interpretation, critical revision of the manuscript for important intellectual content. A. Lecler: study concept and design, critical revision of the manuscript for important intellectual content, study supervision.

\section{Study funding}

No targeted funding reported.

\section{Disclosure}

The authors report no disclosures relevant to the manuscript. Go to Neurology.org/N for full disclosures.

\section{References}

1. Ellika S, Robson CD, Heidary G, Paldino MJ. Morning glory disc anomaly: characteristic MR imaging findings. AJNR Am J Neuroradiol 2013;34:2010-2014.

2. Lit ES, D'Amico DJ. Retinal manifestations of morning glory disc syndrome. Int Ophthalmol Clin 2001;41:131-138. 


\title{
Neurology
}

\author{
Teaching NeuroImages: Morning glory disc anomaly \\ Guillaume Poillon, Perrine Gillard and Augustin Lecler \\ Neurology 2018;91;e1457-e1458 \\ DOI 10.1212/WNL.0000000000006325
}

This information is current as of October 8, 2018

\section{Updated Information \& Services}

References

Citations

Subspecialty Collections

Permissions \& Licensing

Reprints including high resolution figures, can be found at: http://n.neurology.org/content/91/15/e1457.full

This article cites 2 articles, 1 of which you can access for free at: http://n.neurology.org/content/91/15/e1457.full\#ref-list-1

This article has been cited by 2 HighWire-hosted articles: http://n.neurology.org/content/91/15/e1457.full\#\#otherarticles

This article, along with others on similar topics, appears in the following collection(s):

\section{All Neuro-ophthalmology}

http://n.neurology.org/cgi/collection/all_neuroophthalmology

Developmental disorders

http://n.neurology.org/cgi/collection/developmental_disorders

\section{MRI}

http://n.neurology.org/cgi/collection/mri

Information about reproducing this article in parts (figures,tables) or in its entirety can be found online at:

http://www.neurology.org/about/about_the_journal\#permissions

Information about ordering reprints can be found online:

http://n.neurology.org/subscribers/advertise

Neurology ${ }^{\circledR}$ is the official journal of the American Academy of Neurology. Published continuously since 1951, it is now a weekly with 48 issues per year. Copyright () 2018 American Academy of Neurology. All rights reserved. Print ISSN: 0028-3878. Online ISSN: 1526-632X.

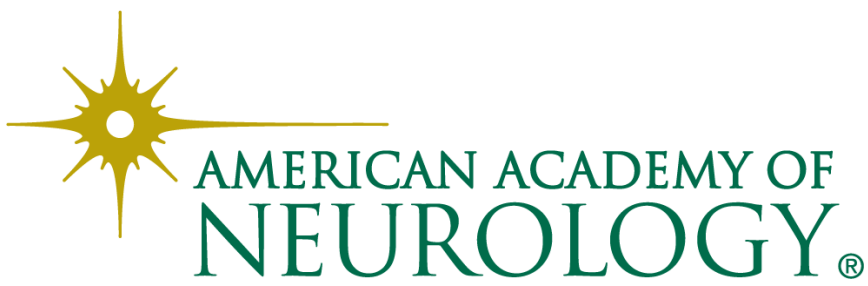

